\title{
APPLICATION OF LEAN SIX SIGMA TO REDUCE THE COST OF REGULATORY NONCOMPLIANCE.
}

\author{
Reham Nour ${ }^{1}$, Chad Laux ${ }^{2}$ \\ ${ }^{1}$ Ph.D. Student, Purdue University, rnour@purdue.edu \\ ${ }^{2}$ Associate Professor, Computer and Information Technology, Purdue University
}

\begin{abstract}
1. Purpose

This research focused on the adoption of Six Sigma within FDA-regulated pharmaceutical companies to design and propose an effective CAPA system for reducing the cost of noncompliance and supporting organizational performance.
\end{abstract}

\section{Design/Methodology/Approach}

This study utilized the DMAIC methodology, in a case study, to improve the CAPA process within a medical device company regulated by the FDA. Critical requirements for compliance CAPA system was defined from FDA sources and a DMAIC model was be applied to improve and maintain CAPA performance.

\section{Findings}

Using the DMAIC approach, the authors identifyed process variation within the current CAPA process. A stepwise-based CAPA model is proposed for company adoption.

\section{Research Limitations/Implications}

This research was limited to the aspects of CAPA regulation as one important regulatory requirement, within the FDA regulatory environment. This study was limited in its description: that being the Six Sigma DMAIC process was utlilzed to define the case study's current CAPA issues and propose a new CAPA system. Further research is needed to confirm these results and application of Six Sigma within the regulatory sector.

\section{Practical Implications}

This research serves as an approach for the Six Sigma practitioner to familiarize, and potentially adopt in similar, highly regulated environments, within the life sciences sector.

\section{Value}

This paper expands knowledge of quality system regulation through this novel application of Six Sigma in designing an effective CAPA approach. This could allow companies to gain a greater understanding of conducting effective systems compliance more efficiently. 


\section{$8^{\text {th }}$ INTERNATIONAL CONFERENCE ON LEAN SIX SIGMA}

\section{Introduction}

Within the pharmaceutical sector, implementing an effective corrective action and preventive action (CAPA) system is critical, not only because it is a regulatory requirement, but, because it is a helpful tool for continuous improvement. It is a mandatory by the regulatory bodies i.e. the U.S. Food and Drug Administration (FDA), that drug and medical devices-based industries adopt a mature CAPA system for three main reasons:

- Regulatory requirements: A prerequisite for ISO-certified and FDA-regulated companies.

- Customer satisfaction: Capability to deal with any customer-related issue and correct any quality problem is crucial for better customer relationship and for sustained customer satisfaction.

- Better business performance: Problems and quality issues would financially impact companies.

Six Sigma methodology is a tactical methodology that has been used in most of industrial sectors for about 25 years to improve process performance. It was established by Motorola in the 1980s and started to be implemented by others such as General Electric.. Six Sigma is a flexible data-driven approach used to save money, improve capabilities and performance, achieve better customer relationships, and therefore, achieve near-perfection performance at all business levels. This approach relies on facts and statistical analytical thinking to detect and eliminate nondesirable variations and defects in the processes. Sigma principles consist of a business strategy and methodology that has the ability to improves business performance and operational efficiency, improves product quality, reduces production costs, and improves customer satisfaction, especially considering the growth of global markets.

Six Sigma DMAIC consists of five stages; Define, Measure, Analyze, Improve, and Control Stage one is 'Define' where opportunities are defined, while stage two 'Measure' is to measure the current process performance. 'Analyze' is the third stage where possible opportunities are analyzed, stage four which is "Improve", where methods to improve performance are proposed, and finally 'Control' where ways to control performance are completed.. Six

Within a healthcare organization, Six Sigma could be used as a catalyst for compliance. Six Sigma consists of several components that ensure the effective running of organization and implementation of a regulatory compliance program. Six Sigma could allow a more consistent compliance program, which has a high value in the compliance field.

In this study, a Six Sigma DMAIC module was applied within a medical device company to improve their CAPA process, with the goal to achieve the required compliance with the FDA regulation. Within this medical device company, this research was conducted on the company's CAPA process within the quality assurance department

\section{Six Sigma and CAPA}

Adopting Six Sigma for the pharmaceutical industry need to pay close diligence attention when identifying customers because the customer definition varies, compared to other industries. For pharmaceutical industries, although the patients are the end customers, there are third-party customers. The real customers are the doctors prescribing drugs, the pharmacist willing to stock certain medicine and the governments who oversee socialized healthcare. These governments have enormous buying power and wield this power to negotiate pricing of pharmaceutical products. 


\section{$8^{\text {th }}$ INTERNATIONAL CONFERENCE ON LEAN SIX SIGMA}

Therefore, pharmaceutical organization should consider these regulatory agencies as one of their customers who help generate additional revenue and profits. Six Sigma can be used to improve the CAPA process by considering the FDA as the customer for CAPA and define their critical requirements then using the model Define, Measure, Analyze, Improve, and Control (DMAIC) to improve the CAPA process performance and sustain improved performance. Adopting the concept and benefits of Six Sigma to create an effective CAPA system (Good CAPA practice) supportsa more efficient and productive business.

There are drug and medical devices-based companies that have implemented Six Sigma, and are successfully using it to accomplish their corporate strategies such as Baxter, Eli Lilly, Johnson \& Johnson, and Novartis (Stückrath 2006), only a few of these firms are listed among the member companies of the International Society for Six Sigma Professionals (ISSSP) (Liu 2005). Although the pharmaceutical/medical device manufacturering sector is a highly controlled sector in order to make sure that all the regulatory requirements are followed and implemented by companies to produce and deliver high-quality products and therefore, protect patients' safety, there are still many critical processes that not meeting the needs of today's marketplace (Cortada et al, 2004).

Finding and following a strategic methodology that helps companies maintain their best compliance status and achieve a continuous business improvement is important. Six Sigma itself is not just a statistical tool, it is a strategic methodology that can be used to produce quantifiable and significant changes within the company by using data, which in turn, is used to operate compliance system and processes to the maximize compliance performance, with the ulitimate goal to finally improve customers' satisfaction (FDA) and reduce compliance costs (Roan \& Jernelid, 2009). Therefore, the ultimate goal for CAPA process improvement is to bring the process to maximum compliance as well as reduce the cost of non-compliance. Tarantino (2008) suggested that having a Six Sigma program in place could help the organization in many ways. One benefit that relates to this study is by reducing variation, which is also what a compliance program aims achieve consistently Table 1 summarizes CAPA aspects that professionals address.

Table 1. CAPA in the literature

\begin{tabular}{|c|c|c|}
\hline Challenges & Failure and success factors & CAPA Elements \\
\hline $\begin{array}{l}\text { - Singer (1999) how to look into } \\
\text { the CAPA system as a "closed } \\
\text { loop" } \\
\text { - Schnoll (2001) the challenge In } \\
\text { define and implement the right } \\
\text { activities and procedures } \\
\text { - Van Wert (2008) to understand } \\
\text { that there will be an endless } \\
\text { number of solutions for } \\
\text { statistically derived problems. } \\
\text { - Compliance focus through } \\
\text { implementing CAPA as an } \\
\text { improvement tool to the } \\
\text { organization main activity } \\
\text { (Biswas, 2008). }\end{array}$ & $\begin{array}{l}\text { - Snyder (2002), the right perspective, } \\
\text { the right strategy, plan, and tools } \\
\text { - Paradies \& Skompski (2002) pointed } \\
\text { out three main failure factors; actual } \\
\text { root causes, management commitment, } \\
\text { and limited ideas and solutions } \\
\text { - Peterson (2005), well trained team on } \\
\text { CAPA activities } \\
\text { - Hoffman (2007), The significant of } \\
\text { implementing pure effective preventive } \\
\text { action } \\
\text { - Mehta (2014) effective root cause } \\
\text { analysis }\end{array}$ & $\begin{array}{l}\text { - Bodea (2008) effective CAPA } \\
\text { policy, well-written procedures, } \\
\text { strong IT support, good } \\
\text { planning, well-trained team, } \\
\text { appropriate actions taken, and } \\
\text { effective measure of the process } \\
\text { performance } \\
\text { - (Hodges, 2010) four element: } \\
\text { documentation, investigation, } \\
\text { CAPA, and measurement } \\
\text { - Another different four elements } \\
\text { by (Hardoroudi \& et al. 2011) } \\
\text { gathering information and data, } \\
\text { investigation, clarification and } \\
\text { making decision }\end{array}$ \\
\hline
\end{tabular}




\section{$8^{\text {th }}$ INTERNATIONAL CONFERENCE ON LEAN SIX SIGMA}

Moreover, In the author opinion adopting a Six Sigma program helps many pharmaceutical companies to eliminate non-added values and allows production operations to change effectively. Therefore, instead of depending on the final quality control and testing, Six Sigma allows organizations to detect and expect problems and errors therefore enhance the process efficacy which ultimately enhances both quality and compliance. This case study applies Six Sigma DMAIC principles, with the goal of improving CAPA. The definition of CAPA requirments, in this case, are through FDA's Warning Letter as criterion for an effective CAPA system.

\section{Case Study}

The company under study is a medical device company regulated by the FDA. The company originally started as a University-industry partnership with a primary focus on developing medical device products. This primary focus rapidly expanded to include other supportive service areas of pre-clinical, clinical, and non-clinical research, medical and scientific writing, as well as regulatory policies and approaches. The case study company CAPA related data are collected. The company CAPA procedure is looked up under their quality assurance department to collect data and gain an insight overview on the current performance of their CAPA process. When bearing in mind process improvement both efficiency and effectiveness should be considered. However, this study will focus only on improving the effectiveness of the CAPA process. Due to time limitation, the last stage of the DMAIC approach (control stages) will be delivered to the case study company as suggestions and recommendations.

\section{Define Phase}

In the Define phase, after evaluation of the FDA CAPA-related warning letters, the voice of the customer (VOC) was defined, This VOC was translated into critical customer requirements (CCRs) which in turn, were used to identify the critical to quality (CTQ's) attributes. A project charter in Figure 1 outlines the project as well as identiying the main stakeholders. The project charter created a roadmap for team members to understand the business value of the project and understand how the project was aligned with the organizational strategy.

\begin{tabular}{|c|c|}
\hline $\begin{array}{l}\text { Corrective and preventive action process within the case } \\
\text { requirements which put them under risk when they get } \\
\text { businesses wise and concordances with other business }\end{array}$ & $\begin{array}{l}\text { ss Case } \\
\text { tudy company not fully implemented per the FDA } \\
\text { spected by the FDA. Additionally, it impacts the company } \\
\text { rtners are compromised. }\end{array}$ \\
\hline $\begin{array}{l}\text { Opportunity Statement } \\
\text { The CAPA process is currently weak. The company needs } \\
\text { to define the gap within their CAPA system. Moreover, } \\
\text { there is an opportunity to improve the process to be } \\
\text { comply with the FDA regulation using the Six Sigma } \\
\text { methodology }\end{array}$ & $\begin{array}{l}\text { Goal Statement } \\
\text { - Identify the gaps within the process } \\
\text { - Suggest solutions and ideas for improvement }\end{array}$ \\
\hline $\begin{array}{l}\text { Project Scope } \\
\text { Improve the CAPA process to bring the process to the } \\
\text { maximum compliance as well as reduce the cost of } \\
\text { Start of Process: Nonconformance issue } \\
\text { End of process: the issue is solved and CAPA is closed } \\
\text { Stakeholders: } \\
\text { - Quality department in the case study company } \\
\text { - FDA (Food and drug administration) }\end{array}$ & $\begin{array}{l}\text { Team Selection } \\
\text { - Quality assurance manager } \\
\text { - } \text { CAPA process administrative } \\
\text { - Six Sigma Black Belt Master candidate }\end{array}$ \\
\hline
\end{tabular}

Figure 1, Project Charter 


\section{$8^{\text {th }}$ INTERNATIONAL CONFERENCE ON LEAN SIX SIGMA}

Critical customer requirements (Table 2) were identified from the norms and criteria for good CAPA practices, and voice of the customer (VOC) analysis. For highly regulated industries, such as medical devices and pharmaceutical companies, the customer (FDA) is the final authority that determines the final value of any regulatory process ( https://www.fda.gov/about-fda/fdahistory/milestones-us-food-and-drug-law ). FDA's decision to approve a company's compliance status is based on a system of critical FDA regulation and requirements.

Table 2. Critical customer requirements

\begin{tabular}{|c|c|c|}
\hline Voice of the customer & Key customer Issue & Critical customer requirements \\
\hline Identify \& Triage & $\begin{array}{l}\text { Identify problem } \\
\text { Assess impact } \\
\text { Quality/regulatory/management } \\
\text { notification }\end{array}$ & $\begin{array}{l}\text { - } \quad \text { Documented procedure(s) and Documentation rules } \\
\text { - } \quad \text { Identify all sources of quality data and analyze them } \\
\text { - }\end{array}$ \\
\hline $\begin{array}{l}\text { Investigate rout } \\
\text { cause/action plan }\end{array}$ & $\begin{array}{l}\text { Investigation process } \\
\text { Proposed corrective /preventive } \\
\text { actions } \\
\text { Plan effectiveness }\end{array}$ & $\begin{array}{l}\text { - } \quad \text { Determine Root cause } \\
\text { - } \text { Well defined action plan } \\
\text { - } \quad \text { Disseminate information } \\
\text { actions prior to implementation }\end{array}$ \\
\hline Implement actions & $\begin{array}{l}\text { Consensus from reviewers } \\
\text { Review \& approve plan } \\
\text { Assess changes }\end{array}$ & $\begin{array}{l}\text { - Implementing, recording and approving changes } \\
\text { - Ensure that the change has no impact to quality }\end{array}$ \\
\hline Verify effectiveness & verify completeness & $\begin{array}{l}\text { - Effectiveness check (establish criteria for } \\
\text { determining whether such corrective action is } \\
\text { effective for its CAPA) } \\
\text { - Measure to ensure problem has been resolved } \\
\text { - Monitor for re-occurring }\end{array}$ \\
\hline Completion \& closing & $\begin{array}{l}\text { Closed CAPA } \\
\text { Compile a report }\end{array}$ & $\begin{array}{ll}\text { - } & \text { Management review } \\
\text { - } & \text { Completed CAPA report with approved signature } \\
\text { - } & \text { Report retained }\end{array}$ \\
\hline
\end{tabular}

Table 3 Process SIPOC

\begin{tabular}{|c|c|c|c|c|}
\hline Supplier & Input & Process & Output & Customer \\
\hline $\begin{array}{l}\text { - Quality data } \\
\text { - Quality problem } \\
\text { - internal audit } \\
\text { - customer } \\
\text { complains } \\
\text { - FDA audit } \\
\text { - third party audit }\end{array}$ & $\begin{array}{l}\text { - problem need CAPA } \\
\text { quality data } \\
\text { analysis } \\
\text { - Tracked processes } \\
\text { data }\end{array}$ & $\begin{array}{l}\text { Tracking other process/ define source of quality } \\
\text { problem } \\
\text { identify the problem that need CAPA } \\
\text { Create a PNCR } \\
\text { QRB approval } \\
\text { Assign responsibility } \\
\text { Create team } \\
\text { Define risk } \\
\text { Root cause analysis } \\
\text { Well define action plan (CA / PA or both) } \\
\text { Verification/validation } \\
\text { QRB approval } \\
\text { Implement action } \\
\text { Assessment of impact } \\
\text { Change control } \\
\text { Effectiveness check } \\
\text { Close CAPA }\end{array}$ & $\begin{array}{l}\text { - Change control } \\
\text { - CAPA reports } \\
\text { - Risk assessment } \\
\text { - Root cause } \\
\text { analysis report } \\
\text { - Impact } \\
\text { - Assessment } \\
\text { - Effection plan } \\
\text { record }\end{array}$ & $\begin{array}{l}\text { - FDA } \\
\text { - Third part } \\
\text { customer } \\
\text { - End user }\end{array}$ \\
\hline
\end{tabular}




\section{$8^{\text {th }}$ INTERNATIONAL CONFERENCE ON LEAN SIX SIGMA}

Table 3 gives a high-level understanding of the CAPA process through a Supplier, Input, Process, Output, Customer (SIPOC) analysis. The SIPOC describes how the process uses relevant inputs, provided by the CAPA process suppliers, to bring the deliverable outputs to the CAPA process customers, primarily the FDA.

\section{Measure Phase}

The second stage of DMAIC was intended to measure the current performance of the CAPA process within the case study company. Thisestablished the process baseline and measured the gap between the current performance and the target performance, defined previously from the VOC in the Define stage. A qualitative analysis of attributes between current and ideal CAPA process was conducted by the team. Table 4 summarizes the identified gaps in the CAPA system.

Table 4. Current performance/ GAP within the system

\begin{tabular}{|c|c|}
\hline Current system performance & Gaps within the system \\
\hline $\begin{array}{l}\text { The system have the following: } \\
\checkmark \text { Documented procedure(s) and Documentation } \\
\quad \text { rules. } \\
\checkmark \text { Risk assessment and prioritization. } \\
\checkmark \text { Well defined action plan. } \\
\checkmark \text { Implementing ,recording and approving changes. } \\
\checkmark \text { Measure to ensure problem has been resolved. } \\
\checkmark \text { Submitting CAPA report biannually for } \\
\quad \text { management review. } \\
\checkmark \text { Completed CAPA report with approved signature. } \\
\checkmark \text { Report retained. }\end{array}$ & $\begin{array}{l}\text { The system lack the following: } \\
\times \text { Identify all sources of quality data and analyze } \\
\text { them with well defined statistical methods. } \\
\times \text { Root cause analysis (no scientific approaches). } \\
\times \text { Criteria for Effectiveness check. } \\
\times \text { Ensure the dissemination of relevant information. } \\
\times \text { Define requirements to verify and/or validate } \\
\text { actions prior to implementation. } \\
\times \text { Ensure that the change has no impact to quality. } \\
\times \text { establish criteria for determining whether such } \\
\text { corrective action is effective for its CAPA. } \\
\times \text { Monitor for re-occurring. }\end{array}$ \\
\hline
\end{tabular}

\section{Analyze Phase}

The Analyze stage was conduted to identify causes for the process gaps identified above. To improve the CAPA process, the Analysis phase was concerned with the evaluation of the ways the work was performed currently in order to identify the reasons why these gaps exist. Figure 2 illustrates the application of 5 'whys' tool used to identify root cause. The deliverable root cause,which was the major output from the analyze stagewas found that no single guideline or CAPA program approach could guide the company to fulfill all the FDA regulatory requirements or bring the best practice to the company's CAPA system. 


\begin{tabular}{|l|l|}
\hline Why? & - CAPA system is not in compliance with the FDA regulation \\
\hline Why? & $\begin{array}{l}\text { - There are gaps between what the FDA required and the current } \\
\text { performance }\end{array}$ \\
\hline Why? & - The FDA requirements are not fully implemented \\
\hline Why? & $\begin{array}{l}\text { - Difficulty in defining and interpreting the CAPA requirement per the } \\
\text { regulations }\end{array}$ \\
Why? $\quad \begin{array}{l}\text { - No single source that clearly defines how to design, develop and implement } \\
\text { a CAPA system that meets all the regulatory requirements }\end{array}$ \\
\hline
\end{tabular}

Figure 2. The 5 Whys root cause analysis

\section{Improve Phase}

Use of a process 'turtle' analysis technique, the team devised a new procedure for meeting regulatory requirements. The CAPA process turtle (figure 3) reveals the need to design a new process able to cover all the regulatory criteria. This proposed model is a stepwise approach as each step acts as an input to the next step. It consists of 11 steps that cover all the CAPA system regulatory requirements to meet best CAPA practices.

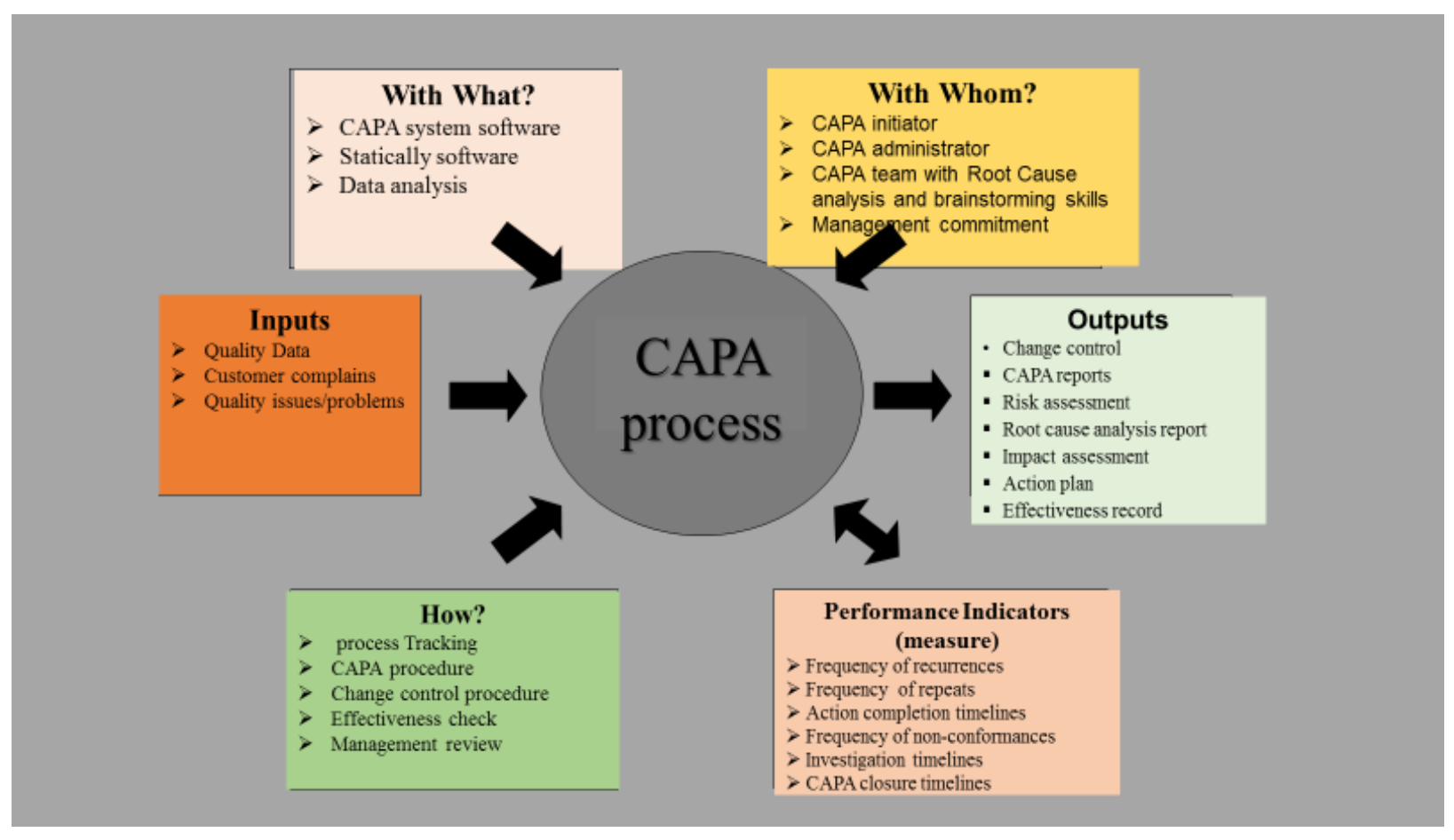

Figure 3. CAPA process turtle analysis 


\section{$8^{\text {th }}$ INTERNATIONAL CONFERENCE ON LEAN SIX SIGMA}

\section{Control Phase}

the last stage of the Six Sigma DMAIC application is the control stage, where alternative design ideas were recommended to the organization, to improve, and ultimately, maintain compliance performance.. The project team created multiple ideas for maintenance. These ideas included:

- Creating a CAPA checklist to ensure that all CAPA regulatory requirements are covered during CAPA detection and execution.

- Using tracking and monitor tool to record and monitor all CAPA activities.

- Categorization of the CAPA finding to facilitate the tracking process.

Develop metrics to measure CAPA process performance and capability.Figure 4 shows a CAPA process improvement cycle, as wheel of continuous improvement, and how the use of the Six Sigma DMAIC principles could allow for the development of a general CAPA model, implementing Six Sigma aspects, to ultimately, control and maintain improved compliance through effective performance.

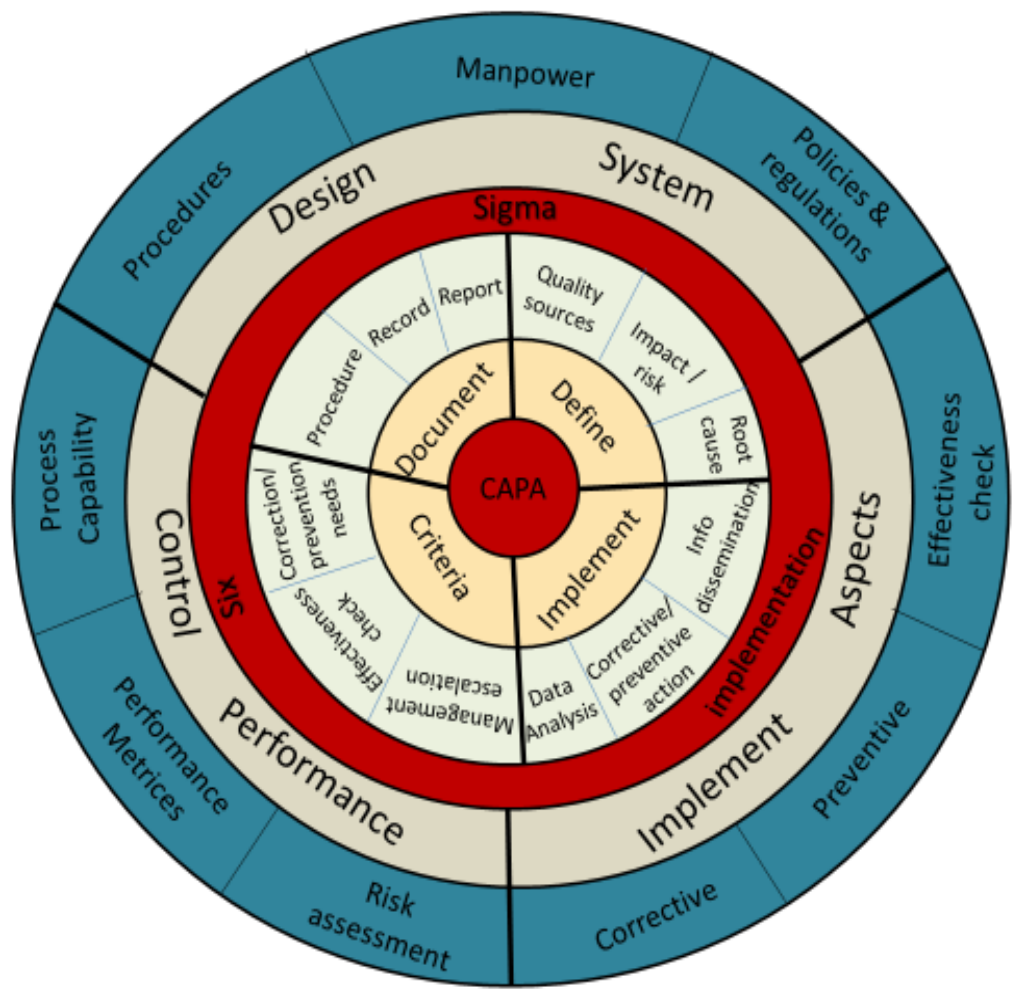

Figure 4. CAPA system performance improvement within Six Sigma principles

\section{Conclusions and Recommendations}

A medical device company, through a case study, applied the Six Sigma DMAIC approach to analyze current CAPA problems, through the lens of FDA compliance, to present changes to the current CAPA process for adoption. A step-wise approach was presented, along with more general, and multi-pronged approach to redesigning an effective CAPA system. This research could be considered descriptively and needs further testing. More empirical research is needed to statistically test the significance of the new proposed model. Additionally, the generalizability of this new model should be examined by applying it to various case studies companies.However, 


\section{$8^{\text {th }}$ INTERNATIONAL CONFERENCE ON LEAN SIX SIGMA}

this research provides a novel application of the Six Sigma DMAIC methodology in improving a CAPA process to meet FDA regulations. This could give pharmaceutical/medical device manufacturers guidance to redesign a more effective CAPA system.

A stepwise-based CAPA model, based upon a process 'turtle' model is proposed to support an organization's compliance with FDA requirements and also for an effective CAPA structure. Other potential adoption principles include the adoption of well-designed checklist(s) to make sure that $t$ CAPA activites are efficiently accomplished. This proposed CAPA model could helps companies in their continuous improvement journeyof compliance and performance. 


\section{$8^{\text {th }}$ INTERNATIONAL CONFERENCE ON LEAN SIX SIGMA}

\section{References}

Ayd, S. (2017) "Managing the Cost of Non-Compliance," Pharmaceutical Technology 41 (11).

Biswas, K. (2008). Future state CAPA management-a productivity improvement tool. Special Edition.

Bodea, G. (2008). What Companies Should Know and Consider When Designing A CAPA System PART I. Special Edition.

Bodea, G. (2008). How to Set Up A CAPA Program From Scratch. Special Edition.

Corrective and Preventive Action, 21 C.F.R. § 820.100. (2017).

Current Good Manufacturing Practices for Finished Pharmaceuticals, 21 C.F.R. § 211. (2017).

https://www.fda.gov/ICECI/EnforcementActions/WarningLetters/ucm278624.htm( accessed on

10-15-2017)

Hardoroudi, A. H., Dareshuri, A. F., Sarkan, H. M., \& Nourizadeh, M. (2011, April). Robust corrective and preventive action (CAPA). In Systems Conference (SysCon), 2011 IEEE International (pp. 177-181). IEEE

Hodges, K. (2010). Corrective and Preventative Action Programs: A Mechanism of Control. Biopharm International,23(3), 28-29.

Hoffman, M. (2007). Thwarting Nonconformity: CAPA vs. Preventive Action. Biomedical Instrumentation \& Technology, 41(5), 390-392.

International Organization for Standardization (n.d.). ISO - International organization for standardization. Retrieved from http://www.iso.org/iso/home.html

International Standard ISO/FDIS 13485:2003(E). (2003). Medical devices - quality management systems - system requirements for regulatory purposes.

Six sigma in Pharmaceutical Manufacturing Industry, Pharma mirror, leading online pharma magazine, ISSN2219 76-3X.

Kozloski, M. A. (2014). Analysis of FDA Guidance on Corrective and Preventive Action Systems: Voice of Customer Perspective (Doctoral dissertation, California State University, Dominguez Hills).

Mehta, Bob. (2014). CAPA and complaints: Ascertaining root cause: Identifying the root cause of corrective and preventive actions and complaints can be challenging, but a number of tools can help. (Regulatory Outlook). Medical Device \& Diagnostic Industry, 36(1), 34.

Paradies, M., \& Skompski, E. (2002). Why people don't develop effective corrective actions. In Human Factors and Power Plants, 2002. Proceedings of the 2002 IEEE 7th Conference on (pp. 2-2). IEEE.

Paradies, M. (2007, August). Improving an existing root cause analysis and corrective action program. In Human Factors and Power Plants and HPRCT 13th Annual Meeting, 2007 IEEE $8^{\text {th }}$ (pp. 75-77). IEEE.

Pérez, J. R. (2011). CAPA for the FDA-regulated Industry. ASQ Quality Press.

Peterson, K. (2005). How to kick-start your CAPA process. Biomedical Instrumentation \& Technology, 39(1), 55-59.

Raj, A. (2016). A review on corrective action and preventive action (CAPA). African Journal of Pharmacy and Pharmacology, 10(1), 1-6

Roan, S., \& Jernelid, M. (2009). Six Sigma strategy applied to the pharmaceutical industry: how customers benefit. 


\section{$8^{\text {th }}$ INTERNATIONAL CONFERENCE ON LEAN SIX SIGMA}

Schnoll, L. (2001). Corrective and preventive action in medical device manufacturing. Quality Progress, 34(11), 75.

Singer, N. (1999). Points to consider when preparing for an FDA inspection under the QSIT management controls sub-system. Journal Association of Food and Drug Officials, 63(4), $10-25$.

Tarantino, A. (2008). Governance, risk, and compliance handbook: technology, finance, environmental, and international guidance and best practices. John Wiley \& Sons.

U.S. v. Barr Laboratories, Inc., 812 F. Supp. 458 (D. NJ 1993). Retrieved from: https://www.leagle.com/decision/19931270812fsupp45811169.xml

Van Wert, J. Ambrose. (2008). Corrective action and preventive action--The "StN" boundary line of effective action. (Global Regulatory Viewpoint.). Journal of Validation Technology, 14(4), 43-46. 